\title{
PEER EFFECTS WITH RANDOM ASSIGNMENT: RESULTS FOR DARTMOUTH ROOMMATES*
}

\author{
BRuce Sacerdote
}

\begin{abstract}
This paper uses a unique data set to measure peer effects among college roommates. Freshman year roommates and dormmates are randomly assigned at Dartmouth College. I find that peers have an impact on grade point average and on decisions to join social groups such as fraternities. Residential peer effects are markedly absent in other major life decisions such as choice of college major. Peer effects in GPA occur at the individual room level, whereas peer effects in fraternity membership occur both at the room level and the entire dorm level. Overall, the data provide strong evidence for the existence of peer effects in student outcomes.
\end{abstract}

\section{INTRODUCTION}

People have long believed that peer quality and behavior are among the most important determinants of student outcomes. This idea is expressed in the Coleman Report [1966], in Supreme Court decisions such as Brown versus Topeka Board of Education (1954), and in the findings of numerous researchers. Betts and Morell [1999] find that high school peer group characteristics affect undergraduate grade point average (GPA). Case and Katz [1991] find large peer effects on youth criminal behavior and drug use. ${ }^{1}$ In a summary of the developmental psychology literature, Harris [1998] claims that parental behavior has no direct effect on child outcomes and that peer effects are the only important environmental factors affecting outcomes. A rich literature on neighborhood effects including Jencks and Mayer [1990], Rosenbaum [1992], and Katz, Kling, and Liebman [2001] shows that neighborhood peers can have profound effects on both adults and children.

The standard approach to measuring peer effects takes observational data and regresses own outcomes (or behavior) on

* I would like to thank Phillip Hobbie and James Spencer at Dartmouth's Computing Services group and Lynn Rosenblum in the Office of Residential Life for helping me assemble the data. I thank Patricia Anderson, Joshua Angrist, Eli Berman, Edward Glaeser, Jonathan Gruber, Lawrence Katz, Douglas Staiger, seminar participants at the National Bureau of Economic Research and the Massachusetts Institute of Technology, and two anonymous referees for helpful comments and encouragement. Thank you to Hilla Talati and Michele Verni for their excellent assistance. I am grateful to Dartmouth College and the National Science Foundation for supporting this work.

1. In another example, Kremer [1997] looks at the effects of parental and neighborhood educational attainment on youth educational attainment.

- 2001 by the President and Fellows of Harvard College and the Massachusetts Institute of Technology.

The Quarterly Journal of Economics, May 2001 
peer outcomes (or behavior). As detailed in Manski [1993], there are several difficulties in interpreting coefficients obtained from this approach. First, individuals generally self-select into neighborhoods, groups, or roommate pairs. This makes it difficult to separate out the selection effect from any actual peer effect. Second, if roommates $i$ and $j$ affect each other simultaneously, then it is difficult to separate out the actual causal effect that $i$ 's outcome has on $j$ 's outcome. ${ }^{2}$ Third, it can be difficult to distinguish empirically between peer effects that are driven by individuals' backgrounds (contextual effects) and peer effects that are driven by individuals' behavior (endogenous effects). ${ }^{3}$

Several authors attempt to solve the reflection problem by designing instruments for peer behavior that are assumed to be exogenous. For example, Case and Katz [1991] and Gaviria and Raphael [1999] instrument for peer behavior using the average behavior of the peers' parents. ${ }^{4}$ Borjas [1992] regresses own behavior on measures of average human capital in the prior generation of one's ethnic group. Evans, Oates, and Schwab [1992] attempt to solve the selection problem by adding an equation to explicitly model the fact that the teens in their data self-select into their peer group. While the aforementioned studies yield interesting and useful results, it is difficult to be certain about the exogeneity of the instruments or the ability of structural models to remove selection problems and deliver consistent estimates of peer effects.

The current paper demonstrates the importance of peer effects in a setting where peers are randomly assigned. Freshmen entering Dartmouth College are randomly assigned to dorms and to roommates thereby eliminating the problem of peers selecting each other based on observable and unobservable characteristics. Random assignment implies that all of a roommate's background variables are uncorrelated with own background characteristics. This allows me to measure a reduced-form effect of student $i$ 's background on his roommate $j$ 's outcomes.

2. Manski calls this the reflection problem.

3. The key distinction between Manski's contextual and endogenous effects is that the latter can have social multipliers through a feedback loop (e.g., positive student behavior leads to more positive behavior).

Throughout the paper I define peer effects broadly to encompass any causal effect from a roommate's background or behavior. My results can also accommodate more restrictive interpretations.

4. In Manski's language, these authors are assuming no contextual effects in order to estimate the endogenous effects. 
By examining a range of outcomes, I am able to differentiate between areas where peer effects are important for this group (e.g., level of academic effort, membership in social organizations) and areas that are unaffected by roommate and dormmate influences (e.g., choice of college major). Peer effects are a major determinant of whether one joins a fraternity/sorority and of which fraternity is selected conditional upon joining. The data do not provide strong evidence that the peer effects on grade point average (GPA) and fraternity membership are nonlinear in roommate's background or outcomes. As in Zimmerman [1999], there is some evidence that interactions between own and roommate background are important. ${ }^{5}$

The size and nature of peer effects in student outcomes are important to social scientists for a variety of reasons. First, it is critical that we better understand the educational production function and the relative importance of peer effects versus other inputs such as teachers and infrastructure (see, for example, Hanushek, Kain, and Rivkin [1998] and Greene, Peterson, and $\mathrm{Du}$ [1997]). It is clearly difficult to think about improving student outcomes in primary and secondary schools until we know which inputs matter. Second, a major question in the economics literature is whether or not the interactions among students lead to large social multipliers (see, for example, Epple and Romano [1998] and Hoxby [2000]). Depending on the nature of the peer effects, there may be social gains from grouping together "high ability" students, or there could be social gains from spreading high ability students evenly among the population. Answers to such questions would help inform the debates on forced desegregation and school voucher programs.

Of course, the setting in this paper differs from a secondary school setting on at least three important dimensions. The students are older, live on campus, and are a highly selected group. ${ }^{6}$ Furthermore, peer effects observed in the data may work through a variety of mechanisms, and I do not distinguish among these. ${ }^{7}$

5. Zimmerman [1999] examines freshmen and their roommates at Williams College.

6. It is not obvious whether such homogeneity would increase or decrease the magnitude of peer effects. On the one hand, more variation leads to more possibilities for information to be exchanged. But, a student may be less open to receiving information from a peer who is radically different from herself.

7. Contextual effects (via roommate background characteristics) could involve a form of social learning as in Ellison and Fudenberg [1995], Banerjee [1992], or Griliches [1958]. Endogenous effects could work through several mecha- 
But the results here are useful for understanding the size and nature of peer effects at the college level. The data are particularly informative for economists interested in human capital formation among prospective high income people. Even though the data are from a highly selective school, there is still much useful variation in the SAT scores and other background measures. ${ }^{8}$ This variation allows me to test for the presence of interactions between roommates' backgrounds and to examine the possibility for social gain through rearranging roommates.

\section{Data Description and Setting}

Dartmouth College is a medium-sized, liberal arts institution located in New Hampshire. Dartmouth is the sixth or seventh most selective undergraduate school in the United States based on incoming test scores and high school class rank. ${ }^{9}$ As part of a policy change in 1993, incoming freshmen are assigned to dorms and roommates randomly (see description below). There are no exclusively freshman dorms, but freshmen are assigned only other freshmen as roommates.

The data come from Dartmouth's database of students and include a full history of housing/dorm assignments and term-byterm academic performance. Pretreatment characteristics include SAT scores, high school class rank, public versus private high school, home state, and an academic index created by the admissions office. This last measure is a weighted average of SAT I scores $($ weight $=1 / 3)$, SAT II scores $($ weight $=1 / 3)$, and rescaled high school class rank (weight $=1 / 3) .{ }^{10}$ Outcomes include GPA, time to graduation, membership in fraternities, choice of major, and participation in athletics.

I have additional pretreatment data from the Survey of In-

nisms such as information gathering as in Young [1993], agglomeration externalities, or endogenous preference formation as in Romer [2000] and Glaeser [1999]. For a comprehensive discussion of these various forms of peer effects and related measurement issues, see Glaeser and Scheinkman [1998].

8 . The math SATs range all the way from perfect scores $(800)$ down to the fiftieth percentile $(420)$. The standard deviation is 67 points which represents about 9 percentile points at the mean.

9. See www.usnews.com and www.dartmouth.edu.

10. The academic index equals (average SAT I)/10 + (average SAT II) $/ 10+$ (converted rank score). The converted rank score (CRS) ranges from $20-80$ and is a nonlinear, noncontinuous function of high school class rank and high school size. The highest possible academic index of 240 would result from having $800 \mathrm{~s}$ on all SATs and a CRS of 80 . 
coming Freshmen which is sponsored by the Higher Education Research Institute at the University of California, Los Angeles. This is a survey of entering freshman across the United States and provides a large set of pretreatment characteristics, attitudes, and expectations. ${ }^{11}$ From the survey I use the following two variables: whether or not the student reports drinking beer in the past year and the student's expectation about the likelihood of graduating with honors. The variables from the survey are available for at most 83 percent of my sample.

Dartmouth freshmen are assigned to dorms and roommates randomly. Each freshman fills out and mails in a brief housing slip, and the slips are then thoroughly shuffled by hand. The assignment process is complicated by the fact that on the form each freshman answers yes or no to the following four statements: 1) I smoke (only 1 percent say yes to this); 2) I like to listen to music while studying; 3) I keep late hours; and 4) I am more neat than messy. Since rooms are separate by gender, there is also a fifth variable for male versus female. ${ }^{12}$ The Office of Residential Life (ORL) groups the forms into 32 separate piles based on gender and the responses to the questions. Within each pile, the forms are shuffled by hand.

The piles are then ordered randomly. Each dorm is filled in the following manner: ORL takes dorm 1 , room 1 and fills it with $1-4$ students from pile 1 (depending on the room size). Dorm 1 , room 2 is filled from pile 2 , and room 3 is filled from pile 3 and so on. Subsequent dorms are filled in a similar manner until all of the freshman have been assigned to rooms and roommates. The effect of this process, as will be shown using the data, is to assign students to dorms and roommates which are random conditional on gender and the four housing questions.

There are 32 blocks that were used for assignment, although only 25 blocks are nonempty. Ninety-nine percent of the sample falls within the sixteen largest blocks because so few people admit to smoking. When I include a sixth blocking variable for people

11. See www.gseis.ucla.edu/heri.

12. Students can also fill out a separate form to request to live in the "substance free" dorm. A small number of students (26) are placed in that dorm, and I drop them from the sample. If the requesting students are not placed in the substance free dorm, they are put back in general pool, and their request does not influence their random placement. To maximize sample size, I include 105 such students in the sample, but also add a sixth blocking variable for whether such a request was made. All results are robust to dropping these 105 students completely or the use of this extra blocking variable. 
who requested but did not get the substance free dorm (see footnote 12), the number of nonempty blocks rises to 41 .

The assignment is random within a block as in Rubin's [1977] "Assignment to Treatment Group on the Basis of a Covariate." With the help of ORL, I retrieved all of the paper forms that the prefreshmen filled out and can control for the pretreatment covariates by measuring peer effects separately within each block. In practice, I do not actually show all of the analysis done block by block. In this case, it is possible to control for the covariates by using ordinary least squares with a separate dummy variable for each block (i.e., each possible combination of gender and answers to the four housing questions). This makes more efficient use of the available data. ${ }^{13}$

The data used are for the graduating classes of 1997 and 1998. I have data from several earlier classes, but these did not have random assignment of roommates. ${ }^{14}$ In calculating the roommate variables, I use the original, randomized freshman fall assignment. Where there is more than one roommate, I average the roommate variables. I started with a sample of 2181 students. Of these, 222 were dropped from the sample because they were placed in singles, 26 were dropped because they were placed in the substance free dorm (see footnote 12), 209 had missing housing forms, and 135 made special requests for specific roommates. This leaves a sample of 1589 students. The breakdown by room group size in my final sample is as follows: 53 percent are in doubles, 44 percent are in triples, and the rest are in quad rooms. ${ }^{15}$

Table I contains summary statistics for this sample. Mean freshman year GPA is 3.20 and this rises consistently throughout the sophomore, junior, and senior years. ${ }^{16}$ The histogram in Figure I shows that the distribution of freshman year GPA is heavily concentrated around 3.30. However, there is still much useful

13. There are functional form assumptions inherent in this method of controlling for the covariates. The analysis has also been done within blocks. The effects are all still present, although of course for some of the smaller blocks the $t$-statistics are diminished.

14. For a comparison of the results with and without selection bias (pre- and post-ORL use of randomization), see Sacerdote [1999]. Within the classes of 1997 and 1998 there are still some people who make special requests for roommates, and I drop these 135 people from the sample. Only 3 percent of people switch roommates during freshman year, and ORL requires a strong reason to do so.

15. In Sacerdote [1999] I show results for rooms of two.

16. Further analysis shows that this is a time to graduation effect rather than grade inflation. 
TABLE I

Summary Statistics for Sample of DaRtmouth Roommates Graduating CLASSES OF 1997 AND 1998

\begin{tabular}{lrrrrr}
\hline \hline \multicolumn{1}{c}{ Variable } & Obs. & Mean & Std. dev. & Min & Max \\
\hline freshman year GPA & 1589 & 3.20 & 0.43 & 0.67 & 4.00 \\
sophomore year GPA & 1552 & 3.28 & 0.44 & 0.30 & 4.00 \\
junior year GPA & 1529 & 3.35 & 0.45 & 0.60 & 4.00 \\
senior year GPA & 1508 & 3.41 & 0.45 & 0.50 & 4.00 \\
roommate freshman year GPA & 1589 & 3.19 & 0.39 & 1.15 & 4.00 \\
fraternity/sorority/coed house & 1589 & 0.49 & 0.50 & 0.00 & 1.00 \\
graduate late & 1589 & 0.03 & 0.18 & 0.00 & 1.00 \\
economics major & 1589 & 0.10 & 0.31 & 0.00 & 1.00 \\
social science major & 1589 & 0.33 & 0.47 & 0.00 & 1.00 \\
science major & 1589 & 0.29 & 0.45 & 0.00 & 1.00 \\
humanities major & 1589 & 0.35 & 0.48 & 0.00 & 1.00 \\
black & 1589 & 0.05 & 0.22 & 0.00 & 1.00 \\
SAT Math & 1589 & 691.26 & 67.08 & 420.00 & 800.00 \\
SAT Verbal & 1589 & 632.86 & 70.07 & 360.00 & 800.00 \\
academic score (incoming) & 1589 & 204.20 & 12.88 & 151.00 & 231.00 \\
high school class rank (incoming) & 993 & 9.14 & 12.27 & 1.00 & 75.00 \\
high school class rank missing & 1589 & 0.38 & 0.48 & 0.00 & 1.00 \\
private high school & 1589 & 0.11 & 0.32 & 0.00 & 1.00 \\
smokes (housing form) & 1589 & 0.01 & 0.12 & 0.00 & 1.00 \\
more neat than messy (housing form) & 1589 & 0.69 & 0.46 & 0.00 & 1.00 \\
stays up late (housing form) & 1589 & 0.60 & 0.49 & 0.00 & 1.00 \\
listens to music (housing form) & 1589 & 0.47 & 0.50 & 0.00 & 1.00 \\
same roommate sophomore year & 1589 & 0.14 & 0.35 & 0.00 & 1.00 \\
HS GPA & 1328 & 3.56 & 0.51 & 2.00 & 4.00 \\
Pre-Dart: drank beer in past year & 1337 & 0.59 & 0.49 & 0.00 & 1.00 \\
\hline \hline
\end{tabular}

Use of beer in past year is coded $0-1$ as follows: $0=$ not at all, occasionally or frequently $=1$. Use of beer and high school GPA come from the UCLA Higher Education Research Institute's Survey of Incoming Freshman. Housing form variables come from Dartmouth's Office of Residential Life. All other data are from Dartmouth's Computing Services Group.

Sample consists of all members of the classes of 1997 and 1998 minus the following four groups: students who were assigned to singles (222), students for whom I could not find housing forms (209), students assigned to the substance free dorm (26), and students who were able to request a specific roommate (135).

variation. If I regress sophomore year GPA on freshman GPA, the $R^{2}$ is .48 which indicates that the cross-sectional variation in freshman GPA is highly predictive of future academic outcomes. ${ }^{17}$

Forty-nine percent of the sample is affiliated with a fraternity or sorority or coed Greek house. This is a binary variable that

17. The point here is that differences in grades are not simply random noise, but rather outcomes which are correlated with future grades and with incoming scores (see Table III for this latter fact). 


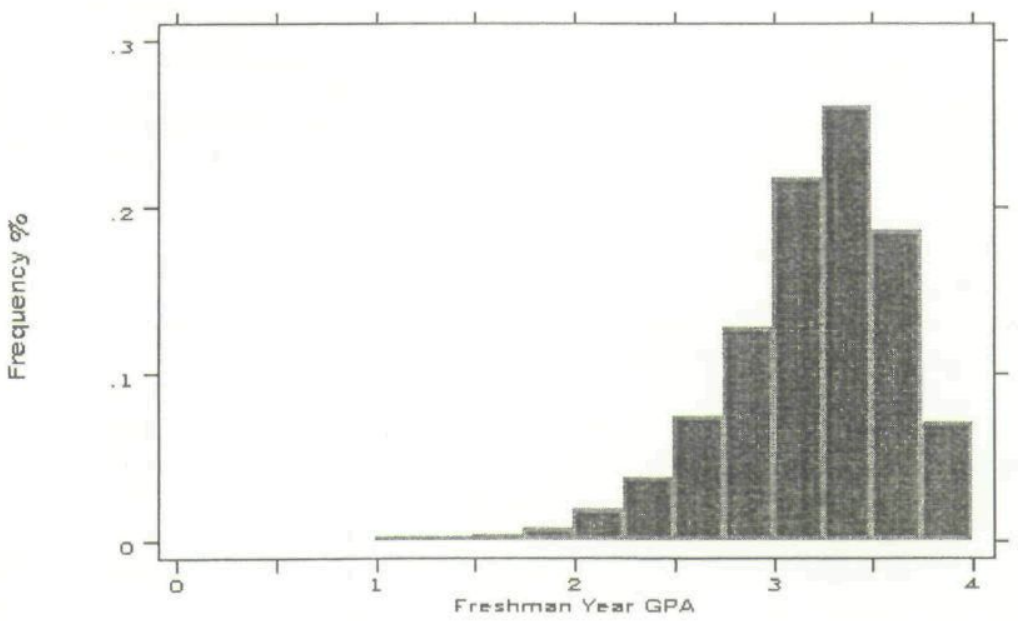

FigURE I

Distribution of Freshman Year GPA

equals one if at some point during his or her Dartmouth career the student joined a fraternity. Most fraternity members join sometime during their sophomore year and remain in the organization through graduation. The proportion joining is similar across men and women (not shown here). I only examine this question as a binary outcome for membership. However, across fraternity members there is wide variation in the amount of time devoted to socializing, exercising, studying, and vacationing with fraternity brothers.

Ten percent of the students graduate as economics majors. As defined by primary major, the students are split roughly in thirds between the social sciences, the natural sciences, and the humanities. Roughly 5 percent of the sample is black, and 11 percent of the students come from private high schools.

From the information on the pre-enrollment housing form, we see that 1 percent of the sample admits to smoking, 69 percent claim to be neat, 60 percent keep late hours, and 47 percent listen to music while studying. This self-reporting of behavior may not be 100 percent accurate, but assignment is still random conditional on the reported answers.

Table II shows that conditional on student $i$ 's responses to the housing questions, there is no relationship between $i$ 's background characteristics and the background characteristics of $i$ 's 
TABLE II

Own Pretreatment Characteristics Regressed on

RoOMmate PRETREatment CHARACTERISTics

Evidence of THE RANDOM AsSignMENT OF ROOMMATES

\begin{tabular}{|c|c|c|c|c|c|}
\hline & $\begin{array}{c}(1) \\
\text { SAT } \\
\text { Math } \\
\text { (self) }\end{array}$ & $\begin{array}{c}(2) \\
\text { SAT } \\
\text { Verbal } \\
\text { (self) }\end{array}$ & $\begin{array}{c}(3) \\
\text { HS } \\
\text { Academic } \\
\text { class index }\end{array}$ & $\begin{array}{c}\text { (4) } \\
\text { HS } \\
\text { Rank }\end{array}$ & $\begin{array}{c}(5) \\
\text { HS } \\
\text { Academic index }\end{array}$ \\
\hline $\begin{array}{l}\text { roommates' math } \\
\text { SAT scores }\end{array}$ & $\begin{array}{c}-0.025 \\
(0.028)\end{array}$ & & & & $\begin{array}{c}-0.005 \\
(0.008)\end{array}$ \\
\hline $\begin{array}{l}\text { roommates' verbal } \\
\text { SAT scores }\end{array}$ & & $\begin{array}{r}-0.009 \\
(0.029)\end{array}$ & & & $\begin{array}{c}-0.005 \\
(0.007)\end{array}$ \\
\hline $\begin{array}{l}\text { roommates' HS } \\
\text { academic scores }\end{array}$ & & & $\begin{array}{c}0.010 \\
(0.028)\end{array}$ & & $\begin{array}{c}0.055 \\
(0.056)\end{array}$ \\
\hline $\begin{array}{l}\text { roommates' HS } \\
\text { class ranks }\end{array}$ & & & & $\begin{array}{c}-0.032 \\
(0.028)\end{array}$ & $\begin{array}{c}0.031 \\
(0.042)\end{array}$ \\
\hline $\begin{array}{l}\text { roommates' HS } \\
\text { class rank } \\
\text { missing }\end{array}$ & & & & & $\begin{array}{c}-0.512 \\
(0.838)\end{array}$ \\
\hline $\begin{array}{l}\text { Dummies for } \\
\text { housing } \\
\text { questions }\end{array}$ & yes & yes & yes & yes & yes \\
\hline $\begin{array}{l}F \text {-test: All } \\
\text { roommate } \\
\text { background } \\
\text { coeff }=0\end{array}$ & & & & & $\begin{array}{c}F(5,1543) \\
=0.50 \\
P>F=.78\end{array}$ \\
\hline$R^{2}$ & .09 & .03 & .04 & .03 & .04 \\
\hline $\mathrm{N}$ & 1589 & 1589 & 1589 & 993 & 1589 \\
\hline
\end{tabular}

Standard errors are in parentheses. In cases with more than one roommate, roommate variables are averaged.

Columns (1)-(5) are OLS. All regressions include 41 dummies representing nonempty blocks based upon responses to the housing questions.

The lack of statistical significance on the coefficients is intended to demonstrate that the assignment process resembles a randomized experiment. In earlier nonrandomly assigned classes (such as the classes of 1995-1996), own and roommate background are highly correlated.

roommate. Regression (1) is an OLS regression of own math SAT score on roommate math SAT score and the blocking variables. The $t$-statistic on roommate SAT score is -.89 indicating that there is no significant relationship between own and roommate math SATs. Regressions (2)-(4) report similar results for verbal SAT score, high school academic index, and high school class rank. In regression (5) I regress own academic index on all four other roommate background scores. I report the $F$-test for the joint significance of roommate background and show that roommate background clearly remains insignificant.

The responses to the housing questions are not critical to this 
result. Nor are the responses significantly correlated with roommate background or outcomes. If I exclude the blocking dummies in regression (5), all of the individual $t$-statistics remain below 1.00 , and the $p$-value on the $F$-test for joint significance only falls to .48 .

Inclusion of the blocking variables does not move the results very much. Nor do the results change significantly with different functional forms to control for the blocking variables. This may indicate that students give very noisy responses to the housing questions or that even "true" housing question answers are not very correlated with observed background and outcomes.

The result of no relationship between roommate background variables only holds in the classes for which ORL randomly assigned roommates. In regressions on some of the nonrandomized data (not reported) I find that roommate math SAT predicts own SAT with a $t$-statistic of 5.0.

\section{Empirical Framework}

Underlying my analysis is a simple framework in which own GPA depends on own level of academic ability (pretreatment), roommate's level of ability, and roommate's GPA. This is clearly a very simplified description of the real world. Undoubtedly, GPA is also influenced by many other factors including peers who are not roommates, parental pressure, choice of courses, etc. However, as long as roommate assignment is orthogonal to all of these other factors, I will be able to obtain unbiased estimates of the effects of roommate background. Roommate peer effects are only one component of the total peer influences experienced by a student; students spend many hours per day interacting with other classmates, athletic teammates, and friends on campus. My estimates based on roommates alone will be very much a lower bound on the total peer effects that influence GPA.

We do not observe actual ability, but instead noisy measures of ability such as SAT scores and high school class rank. Rather than include a complete vector of background information, I use a single academic index (ACA) as the measure of ability (see the data description above for more discussion). ${ }^{18}$ Thus, I am estimating the following model: for two roommates $i$ and $j$,

18. In working with the data, I find that adding additional covariates on top of the index does not greatly increase my ability to predict GPA. 
(1)

$$
\begin{aligned}
G P A_{i}=\delta+\alpha *\left(A C A_{i}+\mu_{i}\right)+\beta *\left(A C A_{j}\right. & \left.+\mu_{j}\right) \\
& +\gamma * G P A_{j}+\epsilon_{i} \\
G P A_{j}=\delta+\alpha *\left(A C A_{j}+\mu_{j}\right)+\beta *\left(A C A_{i}\right. & \left.+\mu_{i}\right) \\
& +\gamma * G P A_{i}+\epsilon_{j} .
\end{aligned}
$$

Here $\mu_{i}$ and $\mu_{j}$ represent the classical measurement error that results from our inability to observe true ability directly. By substituting (2) into (1), I obtain the following reduced form:

$$
\begin{aligned}
G P A_{i} & =\left[1 /\left(1-\gamma^{2}\right)\right] *\left[(1+\gamma) \delta+(\alpha+\gamma \beta) A C A_{i}\right. \\
& \left.+(\beta+\gamma \alpha) A C A_{j}+(\alpha+\gamma \beta) \mu_{i}+(\beta+\gamma \alpha) \mu_{j}+\gamma \epsilon_{j}+\epsilon_{i}\right] .
\end{aligned}
$$

This can be expressed more simply as

$$
G P A_{i}=\pi_{0}+\pi_{1} * A C A_{i}+\pi_{2} * A C A_{j}+\eta,
$$

where $=\pi_{0}, \pi_{1}, \pi_{2}$ are the reduced-form coefficients and $\eta$ is the error term in equation (3).

I estimate (4) using ordinary least squares and interpret the coefficients on $A C A_{i}$ and $A C A_{j}$ to be estimates of the total effect of own observed background and roommate observed background on own GPA. Given the random assignment of roommates, I know that the coefficient $\pi_{2}$ is not driven by selection. To allow a more flexible functional form in some specifications, I break the academic index into three indicator variables to represent whether a student is in the bottom 25 percent, middle 50 percent, or top 25 percent of the distribution for academic index. I interact these three dummies for "own" academic index with the same three dummies for roommates' academic index. This last piece of analysis examines whether or not the interaction between own and roommate background has any significant effect on own freshman year GPA.

I also report results from the OLS regression of $i$ 's GPA on $j$ 's GPA. These coefficients are subject to the reflection problem and cannot be interpreted as causal. But the results do show the degree of correlation in roommates' outcomes.

In this framework, separating out contextual effects from endogenous effects (effects from roommates' current behavior) is equivalent to recovering the original structural parameters $\beta$ and $\gamma$ from equations (1) and (2). To identify the structural parameters, very restrictive assumptions are required. If I assume that $i$ and $j$ 's background ability is not measured with error (i.e., that there are no unobserved background characteristics that matter), 


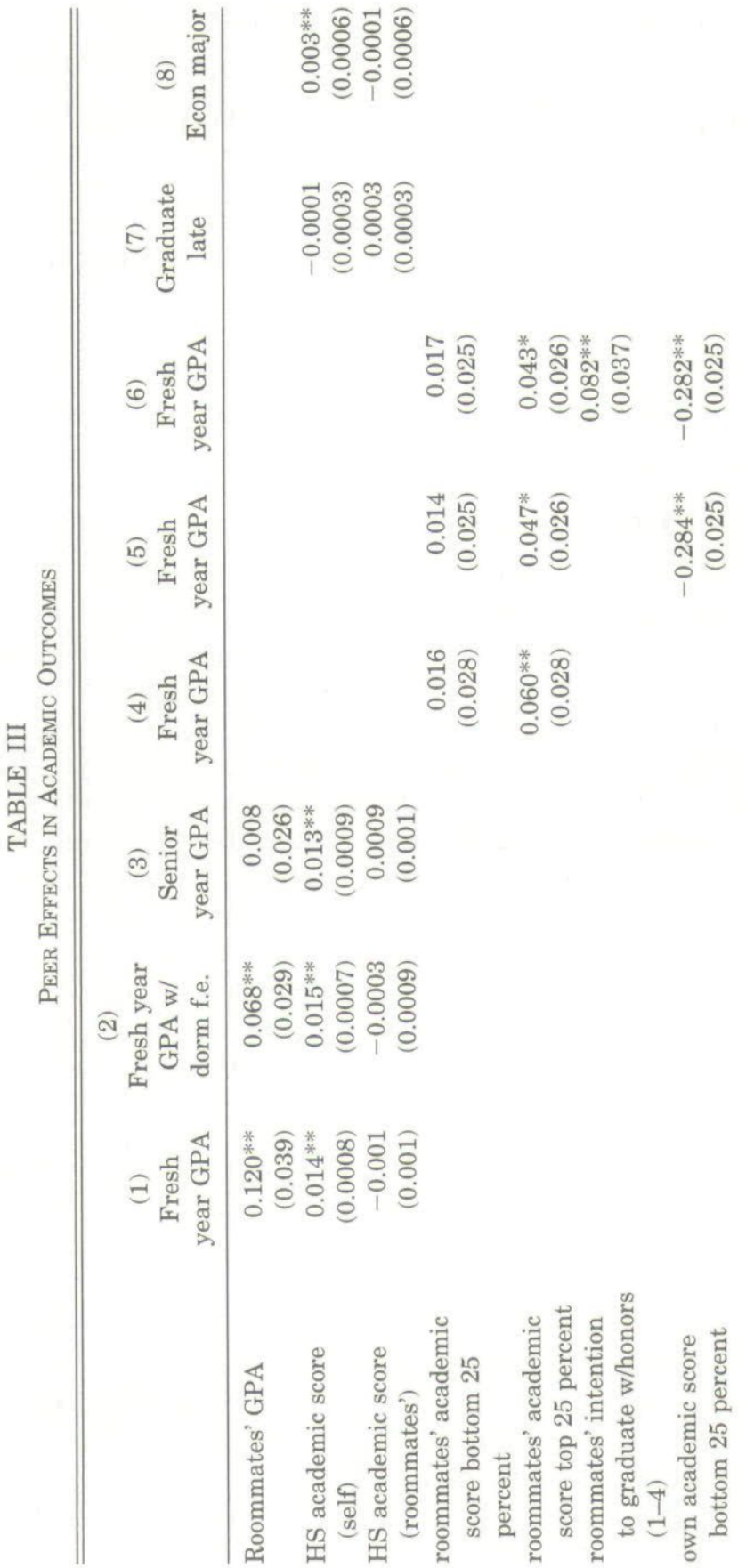




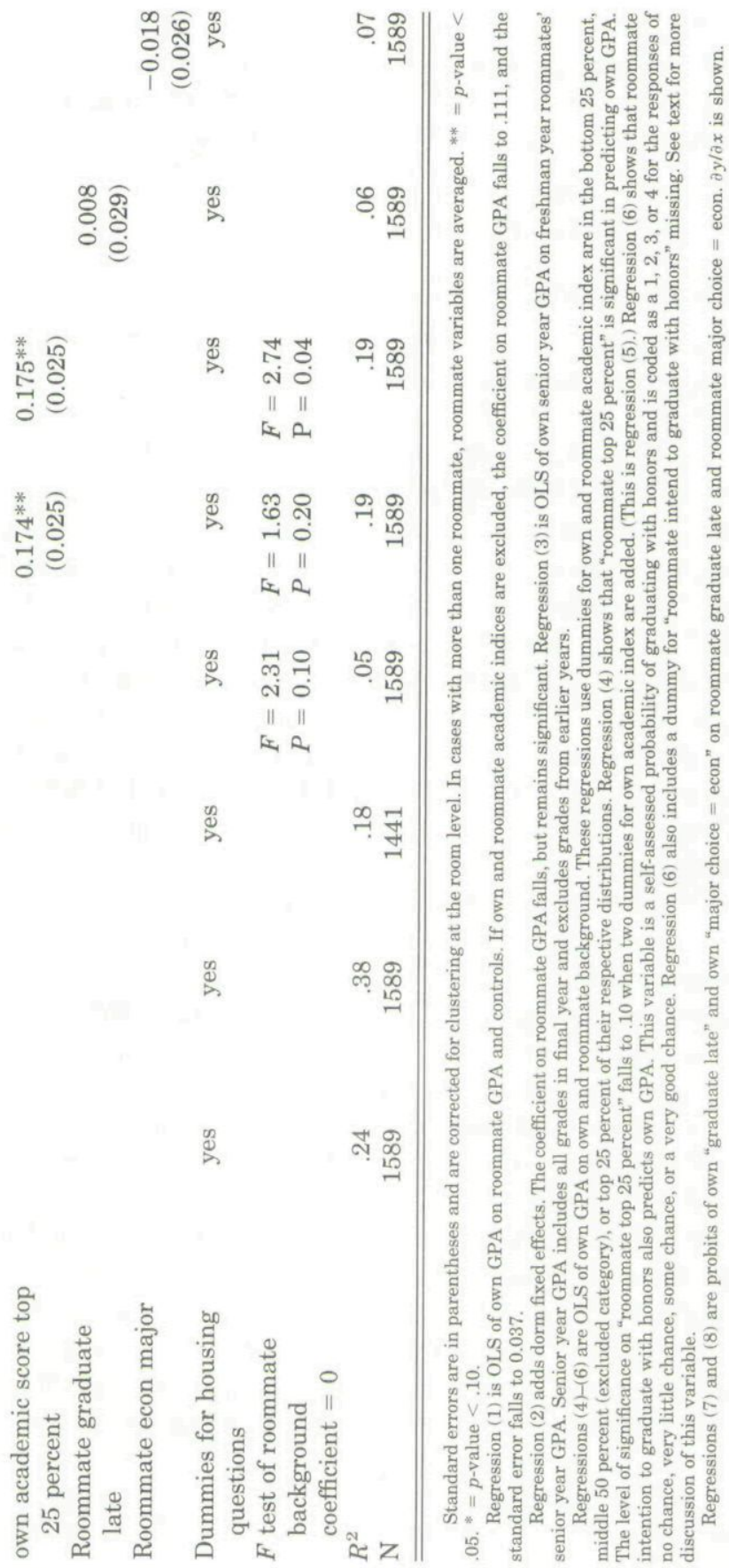


I can solve for $\delta, \alpha, \beta$, and $\gamma$. The estimates of $\beta$ and $\gamma$ are estimates of the causal effects of shifts in roommate academic index and shifts in roommate GPA. This version of the model and its estimation are described in Sacerdote [1999].

\section{Empirical Results}

\section{Results for Academic Outcomes}

Table III contains measures of peer effects in GPA and in whether or not the student graduates late. Column (1) shows the OLS regression of own freshman year GPA on roommates' average freshman GPA. The coefficient on roommate GPA is .12 and is significant with a $t$-statistic of 3.1. One cannot give this coefficient a causal interpretation due to the reflection problem created by regressing outcomes on outcomes. However, since roommates are randomly assigned, the null hypothesis of no peer effects would predict no relationship between own outcomes and roommate outcomes, and the data reject that null. If own and roommate academic index are dropped from the specification in column (1), the coefficient on roommate GPA drops to .11, and the $t$-statistic drops to 2.97. If roommate GPA is excluded from the original equation, the coefficient on roommate academic index remains small and insignificant.

The coefficient on roommate GPA implies that a one-standard-deviation increase in roommate GPA is associated with a .05 increase in own GPA. This coefficient is moderate in size and seems plausible given that we are dealing with students who have reached college age and have already been heavily prescreened for admission to Dartmouth.

Figure II shows a scatter plot of own freshman GPA and roommates' GPA. The points graphed are cell averages rather than individual observations..$^{19}$ The straight line is the OLS regression of own GPA on roommates' GPA and the blocking dummies from the housing questions.

One concern in interpreting the coefficient on roommate GPA in column (1) is that the coefficient may be driven by common shocks that affect all people in a given dorm, rather than a roommate peer effect. For example, if one dorm is constantly

19. The vertical axis shows own GPA controlling for housing question block and the horizontal axis is roommate GPA. 


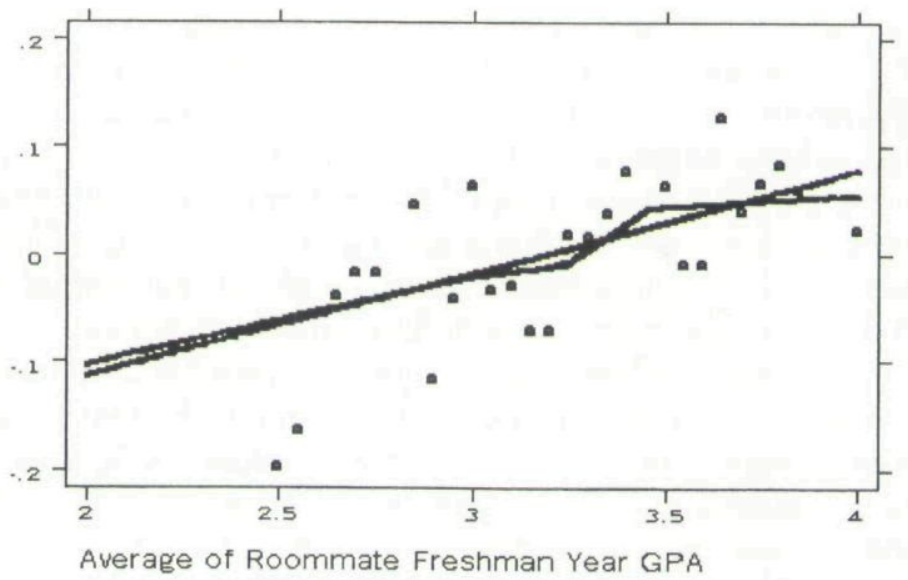

FIGURE II

Freshman GPA versus Roommates' Freshman GPA

Notes: Circles show average of freshman GPA for cells of roommates' GPA. Straight line shows fitted values from OLS of GPA on roommate GPA (controlling for answers to housing questions and own and roommate background). Second line shows spline of freshman GPA on roommates' GPA. Individual slope coefficients in spline are not statistically different from one another.

subjected to loud noise or poor lighting, this might affect GPA. Column (2) of Table III partially addresses this concern by adding dorm level fixed effects for the 29 different dorms. The coefficient on roommate GPA remains statistically significant when dorm fixed effects are added. The coefficient on roommate GPA in column (2) is lower than in column (1), but the difference is not statistically significant.

Table III, regression (3), shows that the "freshman roommate effect" on GPA disappears by senior year. Column (3) contains the OLS regression of own senior year GPA on freshman year roommates' senior year GPA. (Senior year GPA includes only grades from a student's final year at Dartmouth.) Own senior year GPA is not correlated with freshman year roommates' senior year GPA. This is not entirely surprising given that the size of the effect during freshman year is modest. Interestingly, own academic index is just as important to senior year GPA as to freshman year GPA. The coefficient on own academic index is .014 in column (1) and .013 in column (3). This suggests that the importance of incoming ability does not decline as students progress through Dartmouth. 
Regressions (4)-(6) show estimates of the effects of roommate background on own GPA. Here I am regressing own outcomes on randomly assigned roommate background. Given the empirical framework, these coefficients can be interpreted as causal and are not subject to the reflection (endogeneity) problem. For regressions (4)-(6) I create a total of four dummies for whether or not own or roommate academic scores are in the top or bottom 25 percent of the distribution. The middle 50 percent of own and roommate scores are always the omitted categories.

Column (4) shows the regression of own GPA on dummies for "roommate top 25 percent" and "roommate bottom 25 percent." The coefficient on "roommate top 25 percent" is .06 and is statistically significant. This effect is similar to the effect of a onestandard-deviation increase in roommate GPA in regression (1). The coefficient on "roommate bottom 25 percent" is small, positive, and insignificant. As noted earlier, the coefficient on roommate's academic index is not significant if used linearly and by itself (results not reported here). Regression (5) shows that the coefficients on the roommate background variables change only slightly when I add in dummies for "own academic index top 25 percent" and "own academic index bottom 25 percent." The significance level on "roommate top 25 percent" drops from 5 percent to 10 percent.

The coefficient on the "own academic index" dummies are highly significant predictors of GPA and have the expected signs. "Own index top 25 percent" raises own GPA by .174 relative to the omitted category. "Roommate top 25 percent" raises own GPA .047. These numbers imply that the peer effect is 27 percent as large as the own effect. This latter calculation makes the magnitude of the peer effect seem very large. Unfortunately, this finding is not particularly robust to the choice of the own and roommate coefficients used in the comparison.

Regression (6) in Table III shows that my roommate's preenrollment intention to graduate with honors has a positive and statistically significant effect on my GPA. This variable is a self-assessed probability of graduating with honors and is coded as a $1,2,3$, or 4 for the responses of no chance, very little chance, some chance, or a very good chance. The percent of students in each category is 1 percent, 15 percent, 62 percent, and 22 percent, respectively. Unfortunately, the "graduate with honors" variable is only available for one-third of the sample. In regression (6), 
missing values are assigned a value of zero, and a dummy for missing is included. ${ }^{20}$

Regression (7) in Table III shows that there is no significant relationship between own outcome for "graduate late" and freshman year roommate outcome for "graduate late." This labor market outcome may be completely unaffected by the types of peer effects for which I am testing.

The effects on GPA from randomly assigned roommate background are modest in size and statistical significance. The pattern is consistent with Zimmerman [1999]. The correlation in own and roommate outcomes for GPA delivers larger $t$-statistics and is highly robust to changes in specification. I interpret both findings as supporting the existence of peer effects. An alternative interpretation of my findings is that the strong correlation in outcomes is driven by common shocks which affect all roommates together. The common shocks interpretation is somewhat inconsistent with the fact that the coefficient on roommate GPA is robust to inclusion of dorm level effects. In a further attempt to control for location-specific shocks, I have paired each student with a randomly chosen (nonroommate) freshman from the same floor. I find that there is no significant relationship between own GPA and the GPA of a randomly chosen floor member. This provides further evidence that the effect being measured is not a common shock to the dorm or floor.

\section{Results for Choice of Major}

A key manner in which roommates might affect long-term labor market outcomes would be through choice of major. Choice of major has profound implications for career and graduate school choices. However, the data show that randomly assigned roommates have no effect on major. For example, Table III, regression (8), shows a probit of "own major is economics" $(0,1)$ on "roommate's major is economics." Roommate major does not enter significantly; the coefficient on roommate majoring in economics is -.018 with a $t$-statistic of $-.69 .^{21}$

Table IV uses a different statistical test to make the same

20. The result also holds when I limit the sample to cases where roommate "graduate with honors" is nonmissing. When I use a set of three dummy variables rather than including the linear scale, the dummies have large effects on own GPA, but none of the dummies are individually significant.

21. Own academic index enters positively and significantly in the choice to major in economics. In results not shown, I find that this is driven by a positive correlation between math SATs and econ major. 
TABLE IV

Own and Roommate Major Choice Compared with Null Hypothesis of No

Correlation in Major Choice

BOLD SHOWS FRACTION OF SAMPLE IN EACH CELL.

ITALICS SHOWS EXPECTED FRACTION IF OWN CHOICE AND ROOMMATE CHOICE ARE INDEPENDENT (STANDARD ERROR UNDER NULL OF INDEPENDENCE IS SHOWN IN PARENTHESES).

\begin{tabular}{lcccr}
\hline \hline \multicolumn{5}{c}{ Roommate Division of Major } \\
\hline & humanities & sciences & social sciences & total \\
\hline Own division of major & & & & \\
humanities & $\mathbf{0 . 1 3}$ & $\mathbf{0 . 1 1}$ & $\mathbf{0 . 1 1}$ & 0.35 \\
& 0.12 & 0.11 & 0.12 & \\
sciences & $(0.01)$ & $(0.01)$ & $(0.01)$ & \\
& $\mathbf{0 . 1 1}$ & $\mathbf{0 . 1 0}$ & $\mathbf{0 . 1 1}$ & 0.32 \\
& 0.11 & 0.10 & 0.11 & \\
social sciences & $0.01)$ & $(0.01)$ & $(0.01)$ & \\
& $\mathbf{0 . 1 2}$ & $\mathbf{0 . 1 1}$ & $\mathbf{0 . 1 1}$ & 0.33 \\
& 0.12 & 0.11 & 0.11 & \\
total & $(0.01)$ & $(0.01)$ & $(0.01)$ & \multirow{2}{*}{$\mathrm{N}$} \\
$\mathrm{N}=842$ & 0.35 & 0.32 & 0.33 & 1.00 \\
\hline \hline
\end{tabular}

Analysis done only for rooms with exactly two students.

point. I limit the sample to rooms of two. I compare the fraction of roommate pairs with the same major to the fraction that would be expected under a null of independence across roommates. For example, since 35 percent of the students choose a major within the humanities division, under independence, one would expect 12.3 percent $(.35 * .35)$ of all roommate pairs to contain two humanities majors with a standard error of 1 percent. In the data, 13 percent of pairs contain two humanities majors, and I accept the null of independence. ${ }^{22}$

\section{Results for Social Outcomes}

Table V, regression (1), shows a probit of "member of fraternity/sorority" on freshman year roommate decision to join. (Par-

22. I have also used the data from the Survey of Incoming Freshman to examine the relationship between a student's intended major (pre-enrollment) and actual major. Stated intention of major is only weakly predictive of actual major; for example, the $R^{2}$ in a regression of "major in econ" on "intend to major in econ" is only .01. High school scores and grades are actually more predictive of future major choice. 
TABLE V

Peer EfFects in Social OUtcomes

\begin{tabular}{|c|c|c|c|c|}
\hline & $\begin{array}{l}\text { (1) } \\
\text { Member } \\
\text { frat/ } \\
\text { soror }\end{array}$ & $\begin{array}{l}(2) \\
\text { Member } \\
\text { frat/ } \\
\text { soror }\end{array}$ & $\begin{array}{l}\text { (3) } \\
\text { Member } \\
\text { frat/ } \\
\text { soror }\end{array}$ & $\begin{array}{l}\text { (4) } \\
\text { Varsity } \\
\text { athlete }\end{array}$ \\
\hline $\begin{array}{l}\text { roommate member of } \\
\text { fraternity/sorority/coed } \\
\text { dorm average of } \\
\text { fraternity/sorority/coed }\end{array}$ & $\begin{array}{r}0.078^{* *} \\
(0.038)\end{array}$ & $\begin{array}{r}0.056 \\
(0.037) \\
0.321^{* *} \\
(0.135)\end{array}$ & & \\
\hline roommate varsity athlete & & & & $\begin{array}{r}0.045 \\
(0.033)\end{array}$ \\
\hline HS academic score (self) & $\begin{array}{r}0.0098 \\
(0.0010)\end{array}$ & $\begin{array}{r}0.0011 \\
(0.0011)\end{array}$ & $\begin{array}{r}0.0010 \\
(0.0011)\end{array}$ & $\begin{array}{r}-0.004^{* *} \\
(0.001)\end{array}$ \\
\hline $\begin{array}{l}\text { HS academic score } \\
\text { (roommates') }\end{array}$ & $\begin{array}{l}-0.0017 \\
(0.0011)\end{array}$ & $\begin{array}{l}-0.0016 \\
(0.0011)\end{array}$ & $\begin{array}{l}-0.0016 \\
(0.0011)\end{array}$ & $\begin{array}{l}-0.0002 \\
(0.0007)\end{array}$ \\
\hline $\begin{array}{l}\text { Own use of beer in high } \\
\text { school }(0-1)\end{array}$ & & & $\begin{array}{r}0.135^{* *} \\
(0.038)\end{array}$ & \\
\hline $\begin{array}{l}\text { Roommates' use of beer } \\
\text { in high school }(0-1)\end{array}$ & & & $\begin{array}{l}-0.025 \\
(0.026) \\
(0.026)\end{array}$ & \\
\hline $\begin{array}{l}\text { Dormmates' use of beer } \\
\text { in high school }(0-1)\end{array}$ & & & $\begin{array}{r}0.287^{* *} \\
(0.146)\end{array}$ & \\
\hline $\begin{array}{l}\text { Dummies for housing } \\
\text { questions }\end{array}$ & yes & yes & yes & yes \\
\hline$R^{2}$ & .02 & .02 & .03 & .05 \\
\hline $\mathrm{N}$ & 1589 & 1589 & 1589 & 1589 \\
\hline
\end{tabular}

Standard errors are in parentheses and are corrected for clustering at the room level. In cases with more than one roommate, roommate variables are averaged. $* *=p$-value $<.05$.

Columns (1)-(4) are Probits. $\partial y / \partial x$ is shown.

In regression (2), dorm average of frat membership excludes own observation, and standard errors are corrected for clustering at dorm level.

In regression (3), use of beer in past year is coded $0-1$ as follows: $0=$ not at all, occasionally or frequently $=1$. Dorm use of beer excludes own room and standard errors are corrected for clustering at dorm level.

tials are reported rather than probit coefficients.) If my freshman year roommate joins a fraternity, I am 8 percent more likely to do so myself. This occurs in spite of the fact that students do not even execute this decision during their freshmen year. Students are not allowed to join until sophomore year, and only 16 percent of people keep any of the same roommates.

More remarkable is the frequency with which students join the same house as their randomly assigned roommate. When I limit the sample to rooms of two where both roommates have joined a fraternity, I find that 27 percent of the roommate pairs 
join the same house. Under the null of no peer effect (independence), this would occur only 5 percent of the time with a standard error of 1 percent.

Table V, regression (2), examines the level of housing unit aggregation at which the fraternity peer effect takes place. Roommate participation is associated with a 6 percent increase in the probability of own participation. However, the dorm level of participation (excluding own room) is also significant and has the much larger coefficient of 32 percent. This provides evidence that the relevant group for the social interactions that lead to participation include all of one's dormmates. Floor level of participation in fraternities matters, but this effect disappears when dorm level participation is included in the regression.

In Sacerdote [1999] I show that there is very high variance in participation rates across dorms (i.e., some dorms have a large number of freshman who participate and other dorms have a very low number). Furthermore, the high and low participation dorms shuffle each year as the freshmen in the dorm change. This is consistent with the model of social interactions in Glaeser, Sacerdote, and Scheinkman [1996]. In contrast, the peer effect in GPA does not display any dorm level or floor level effect; it is observed only at the room level.

In Table V, column (3), I regress own decision to join on own, roommate, and average dormmate use of beer in high school. (The dorm average excludes own room.) Own use of beer in high school has a large effect on own participation and a $t$-statistic of 3.5. Roommate use of beer has no effect, but average dorm use has a coefficient of .29 and a $t$-statistic of 1.97. This again implies that there is a dorm level peer effect which contributes to fraternity participation.

Regression (4) uses varsity athlete status as the outcome of interest. I run a probit of own participation in varsity athletics on roommate participation and show that the slope is not statistically different from zero.

\section{Possible Nonlinearities in Peer Effects}

Another question of economic interest is whether or not roommate background has a nonlinear effect on own outcome. We can see from Table III, regression (4), that "roommate index top 25 percent" appears to benefit own GPA modestly and that "roommate bottom 25 percent" does not appear to have any effect. 
Further attempts to define any nonlinearity are not fruitful. In Figure II, I show a spline fit between own GPA and roommate GPA. The slopes on the segments of the spline are not statistically different from each other. And the spline is remarkably similar to the linear regression also shown in the figure.

As in Zimmerman [1999], there is some modest evidence of an interaction between own and roommate background. To examine this question, I create three dummy variables for own academic index: bottom 25 percent, middle 50 percent, and top 25 percent. I interact these with the equivalent three dummies for the roommates. Table VI shows the coefficients from a regression of own freshman GPA on the interaction terms. The combination own $=$ middle and roommate $=$ middle is the excluded category ${ }^{23}$

Unsurprisingly, own GPA is higher when own academic index is high, and own GPA is low when own academic index is low. But the dummies for roommate index also affect own outcome. The effect of (own $=$ bottom, roommate $=$ bottom) is -.331 which is worse that the effect of (own = bottom, roommate $=$ top) which is -.16 . The $F$-test for the difference between these coefficients has a $p$-value of .013. The results imply that top roommates can help a student from the bottom of the distribution. Row 3 shows that top roommates also can help a student in the top of the distribution. This last result is significant at the 10 percent level.

Bottom roommates do not seem to deliver any effect that is statistically worse than having a middle roommate. This can be seen by holding own academic index constant (any of the three rows) and switching the roommate category from bottom to middle. Furthermore, middle students do not appear to be helped or hurt much by their roommates. The coefficient on (own $=$ middle, roommate $=$ bottom) is .039 and is not statistically different from the coefficient on (own $=$ middle, roommate $=$ top) which is -.019 .

If these results held more generally, then social gains could be created by redistributing roommates. Top students could be moved away from pairings with middle students since the middle students are not benefiting anyway. The top students could be helpful either to other top students or to bottom

23. There is a total of fifteen indicator variables including six level effect dummies and nine interaction terms. A saturated model will contain eight of these indicator variables plus an intercept. 
TABLE VI

INTERACTION BETWEEN OWN BACKGROUND AND ROOMMATE BACKGROUND

EFFECT ON OWN FRESHMAN GPA

Relative to Own Academic IndeX = Middle, RoOmmate's = Middle

\begin{tabular}{llll}
\hline \hline & \multicolumn{3}{c}{ Roommate academic index } \\
\cline { 2 - 4 } Own academic index & Bottom 25\% & Middle 50\% & Top 25\% \\
\hline bottom 25 percent & $-0.331^{* *}$ & $-0.304^{* *}$ & $-.160^{* *}$ \\
& $(0.056)$ & $(0.035)$ & $(0.049)$ \\
middle 50 percent & 0.039 & 0 & -.019 \\
& $(0.034)$ & & $(0.036)$ \\
top 25 percent & $0.146^{* *}$ & $0.159^{* *}$ & $0.243^{* *}$ \\
& $(0.045)$ & $(0.037)$ & $(0.044)$ \\
\hline \hline
\end{tabular}

Mean freshman GPA is 3.20. Standard errors are in parentheses and are adjusted for room level clustering. ${ }^{* *}=p$-value $<.05 . \mathrm{N}=1589$.

Coefficients are from the following regression of GPA on $(0,1)$ indicator variables: $G P A_{i}=\beta 0+\beta 1 *$ $($ own $=$ bottom, roommate $=$ bottom $)+\beta 2 *($ own $=$ bottom, roommate $=$ middle $)+\beta 3 *($ own $=$ bottom, roommate $=$ top $)+\beta 4 *($ own $=$ middle, roommate $=$ bottom $)+\beta 5 *($ own $=$ middle, roommate $=$ top $)+\beta 6$ $*($ own $=$ top, roommate $=$ bottom $)+\beta 7 *($ own $=$ top, roommate $=$ middle $)+\beta 8 *($ own $=$ top, roommate $=$ top) $+\gamma \cdot \mathbf{X}+\epsilon_{i} \mathbf{X}$ is a vector of dummies for the student's choices on the housing forms.

$F$-test on $($ own $=$ bottom, roommate $=$ bottom $)=($ own $=$ bottom, roommate $=$ top $): F(1,704)=6.27$, $p=0.013$. This shows that bottom people matched with top roommates outperform bottom people matched with bottom roommates.

$F$-test on $($ own $=$ top, roommate $=$ top $)=($ own $=$ top, roommate $=$ bottom $): F(1,704)=3.31, p=$ 0.0691 . This shows that top people matched with top roommates outperform top people matched with bottom roommates. This result is significant at the .10 level.

Redistribution experiment 1 . Consider two rooms. One has two top roommates, and one has two bottom roommates. Rearrange into two "mixed" rooms, each of which contains one top and one bottom person. The two top people are estimated to each lose a benefit to GPA of $.10=.24-.14$ for a combined loss of .20. The bottom people each gain .17 for a combined gain of .34 and a net "social gain" of .14 . An $F$-test on this gain of .14 yields a $p$-value of .42 . I find that the "redistribution" experiment does not yield statistically significant gains.

Redistribution experiment 2: Consider two rooms. Each has one middle and one top person. Rearrange such that the top people are together and the middle people are together. The top people each gain .084, and the middle people each gain .019 (insignificantly) for a net social gain of .206 . The $F$-test on this gain has $p=$ 0.066 and is significant at the .10 level.

students. Such an experiment is considered in the notes to Table VI. I consider breaking up two mixed pairs of one top and one middle student each to form two homogeneous pairs of two top students and two middle students. The top people would each gain .084 and each of the middle people would gain .019 for a total social gain of .206 in GPA. The $F$-test on the social gain has a $p$-value of .066 . However, such results on redistribution of students are certainly more suggestive than conclusive.

\section{CONCLUSION}

Roommate peer effects are important influences in freshman year GPA and in decisions to join social organizations. Roommate 
effects are not important in determining choice of major. This might indicate that peer effects are smaller the more directly a decision is related to labor market activities. However, fraternity membership is important for career networks and for lifelong friendships which ultimately may have a high impact on outcomes. The peer effect for fraternity membership is stronger at the dormitory level than at the individual room level, but the opposite is true for GPA. This provides some evidence that the reference group or relevant peer group can differ dramatically across different activities and outcomes.

The results demonstrate that even within a group of highly selected college age students, peer effects are important to understanding student outcomes. Peer effects may be even more critical and long lasting earlier in student's lives (i.e., high school or junior high) or in a context where there is more student heterogeneity. A fruitful area of future research would be to examine similar data in other educational settings.

\section{Dartmouth COLLEge}

\section{REFERENCES}

Banerjee, Abhijit V., "A Simple Model of Herd Behavior," Quarterly Journal of Economics, CVII (1992), 797-817.

Betts, Julian R., and Darlene Morell, "The Determinants of Undergraduate GPA: The Relative Importance of Family Background, High School Resources, and Peer Group Effects," Journal of Human Resources, XXXIV (1999), 268-293.

Borjas, George J., "Ethnic Capital and Intergenerational Mobility," Quarterly Journal of Economics, CVII (1992), 123-150.

Case, Anne C., and Lawrence F. Katz, "The Company You Keep: The Effect of Family and Neighborhood on Disadvantaged Youths," National Bureau of Economic Research Working Paper No. 3705, 1991.

Coleman, James Samuel, et al., Equality of Educational Opportunity (Washington, DC: U. S. Government Printing Office, 1966).

Ellison, Glenn, and Drew Fudenberg, "Word-of-Mouth Communication and Social Learning," Quarterly Journal of Economics, CX (1995), 93-125.

Epple, Dennis, and Richard Romano, "Competition between Private and Public Schools, Vouchers, and Peer Group Effects," American Economic Review, LXXXVIII (1998), 33-62.

Evans, William N., Wallace E. Oates, and Robert M. Schwab, "Measuring Peer Group Effects: A Study of Teenage Behavior," Journal of Political Economy, C (1992), 966-991.

Gaviria, Alejandro, and Stephen Raphael, "School Based Peer Effects and Juvenile Behavior," University of California, San Diego, Department of Economics Working Paper No. 97/21, 1999.

Glaeser, Edward L., "The Endogenous Formation of Values," mimeograph, Harvard University, 1999.

Glaeser, Edward L., Bruce I. Sacerdote, and José Scheinkman, "Crime and Social Interactions," Quarterly Journal of Economics, CXI (1996), 507-548.

Glaeser, Edward L., and José Scheinkman, "Measuring Social Interactions," mimeograph, Harvard University and Princeton University, 1998. 
Greene, Jay, Paul Peterson, and Jiangtao Du, "Effectiveness of School Choice: The Milwaukee Experiment," mimeograph, Harvard University, 1997.

Griliches, Zvi, "Research Costs and Social Returns: Hybrid Corn and Related Innovations," Journal of Political Economy, LXVI (1958), 419-431.

Hanushek, Eric A., John F. Kain, and Steven G. Rivkin, "Do Higher Salaries Buy Better Teachers?" mimeograph, 1998.

Harris, Judith Rich, The Nurture Assumption: Why Children Turn Out The Way They Do (New York, NY: Free Press, 1998).

Hoxby, Caroline M., "Does Competition among Public Schools Benefit Students and Taxpayers?" American Economic Review, XC (2000), 1209-1238.

Jencks, Christopher, and Susan E. Mayer, "The Social Consequences of Growing up in a Poor Neighborhood," in Inner-City Poverty in the United States, L. E. Lynn, Jr. and M. G. H. McGeary, eds. (Washington, DC: National Academy Press, 1990).

Katz, Lawrence F., Jeffrey R. Kling, and Jeffrey B. Liebman, "Moving to Opportunity in Boston: Early Results of a Randomized Mobility Experiment," Quarterly Journal of Economics, CXVI (2001), 607-654.

Kremer, Michael, "How Much Does Sorting Increase Inequality?" Quarterly Journal of Economics, CXII (1997), 115-139.

Manski, Charles F., "Identification of Endogenous Social Effects: The Reflection Problem," Review of Economic Studies, LX (1993), 531-542.

Romer, Paul M., "Thinking and Feeling," American Economic Review, XC (2000), $439-443$.

Rosenbaum, James E., "Black Pioneers-Do Their Moves to the Suburbs Increase Economic Opportunity for Mothers and Children?" Housing Policy Debate, II (1992), 1179-1209.

Rubin, Donald B., "Assignment to Treatment Group on the Basis of a Covariate," Journal of Educational Statistics, II (1977), 1-26.

Sacerdote, Bruce I., "Peer Effects with Random Assignment: Results for Dartmouth Roommates," National Bureau of Economic Research Working Paper No. 7469,1999 .

Young, H. Peyton, "The Evolution of Conventions," Econometrica, LXI (1993), $57-84$.

Zimmerman, David J., "Peer Effects in Academic Outcomes: Evidence from a Natural Experiment," Williams Project on the Economics of Higher Education Discussion Paper No. 52, 1999. 
Copyright of Quarterly Journal of Economics is the property of MIT Press. The copyright in an individual article may be maintained by the author in certain cases. Content may not be copied or emailed to multiple sites or posted to a listserv without the copyright holder's express written permission. However, users may print, download, or email articles for individual use. 